Jurnal Lakon, 8 (2) 2019

(61-69)

\title{
BALINESE DAUGHTER AND FEMINIST FATHER IN KOPLAK BY OKA RUSMINI
}

Anak Perempuan Bali dan Ayah feminis dalam Koplak Karya Oka Rusmini

\author{
ANINDYA KUSUMA WARDANI \\ Program Studi Magister Kajian Sastra dan Budaya \\ Fakultas Ilmu Budaya Universitas Airlangga \\ Jl. Dharmawangsa Dalam Selatan, Surabaya 60286 \\ e-mail: anindyakusuma40@gmail.com
}

\begin{abstract}
Balinese women and patriarchy are terms which closely related. They commonly appear at the same time. Can this stereotype be negotiated? In the work of Oka Rusmini's Koplak, this phenomenon is tried to be negotiated. The appearance of women who are living freely from patriarchal culture is shown through the whole book. It makes a new perspective that patriarchy in Bali can be negotiated. The study aims to show that Balinese women are no longer related to the word patriarchy and they can live their life. Using Feminism theory, Koplak will be examined and seen from a feminist perspective. The analysis activity will use a descriptive-qualitative method. There are two results of the study, showing that nowadays Balinese women can live without a burden of patriarchal, even they have their culture. The culture can be negotiated and the appearance of the feminist father shows that the parent's role in family can help Balinese women being free from patriarchal culture. It also shows that the word feminist is not always given to women.
\end{abstract}

Keywords: Balinese women, Feminism, Men Feminism

Abstrak: Perempuan Bali dan patriarki merupakan dua istilah yang sangat dekat hubungannya. Keduanya juga sering muncul dalam waktu dan lingkup yang sama. Namun, apakah pandangan ini dapat dinegosiasi? Dalam karya Oka Rusmini berjudul Koplak, fenomena ini sedang dinegosiasi. Kehadiran tokoh wanita yang hidup bebas tanpa adanya beban budaya patriarki muncul sepanjang cerita. Hal ini membuat perspektif baru tentang kondisi budaya patriarki di Bali yang ternyata dapat dinegosiasi. Tujuan dari studi ini adalah menunjukkan bagaimana perempuan Bali tidak lagi terkait dengan budaya patriarki. Novel ini akan dikaji melalui perspektif feminism. Metode yang akan digunakan ialah deskriptif-kualitatif. Melalui proses analisis, ada dua kesimpulan yang didapat yaitu pada masa kini perempuan Bali dapat hidup bebas tanpa terbatasi oleh budaya patriarki, yang menunjukkan jika patriarki merupakan budaya yang dapat dinegosiasi. Kemunculan seorang ayah yang juga seorang feminis menunjukkan jika peran orang tua dalam membebaskan wanita dari budaya patriarki sangatlah penting adanya.

Kata-kata Kunci: Feminisme, Feminis Pria, Perempuan Bali

\section{INTRODUCTION}

"Aku paham, tetapi sebagai lelaki Bali kau tidak boleh egois. Kau harus memiliki anak lelaki. Konon, anak lelakilah yang kelak bisa menuntunmu ke tempat yang lebih baik. Membuat arwahmu mendapat tempat yang lebih nyaman (Rusmini, 2019, p. 158)."

Jurnal Lakon: Kajian Sastra dan Budaya 
Translation:

I understand, but as a Balinese man, you are not supposed to be selfish. You have to have a son. Reputedly, a son can guide you to a better place. Make your soul has a greater place (Rusmini, 2019, p. 158).

The quotation above is taken from Rusmini's work entitled Koplak. Koplak is a story of a perbekel, a headman, named Koplak in Sawut Village, a fictional place in Bali. The quotation is taken from a little conversation between Koplak and his friend talking about how valuable his life if he has a son. As it is seen from the quotation above, Koplak's friend asks him to have another kid, but it supposed to be a son. It happens because they believe a son can lead the father into a better place when he dies. It can be sensed that there is a specialty of a male in Balinese culture.

Due to this specialty, women in Bali often being forgotten and treated unequally. It is quite common that women in Bali cannot move freely because of patriarchal values. Patriarchy is described as "the lack of social power that leads to the subordination and oppression of women (Swirsky \& Angelone, 2015)." In Bali, patriarchal values are developed from patrilinear values (Widayani \& Hartati, 2014). Patrilinear culture is a value that is centered on male specialties on many occasions, such as in marriage which male is older and has higher educational status and in inheritance which woman does not receive any (Sudarta, 2017). Concluding from this culture, it is quite hard to find a woman who can live free or be treated equally in Bali.
Even though in the Koplak by Rusmini, it shows how a son is regarded to be special but this work does not have any intention of legitimating male specialty, otherwise the majority of the book talking about a father whose represented by Koplak raises his daughter to live free from the patriarchal culture. This book is trying to fight for the existence of women in society. It makes the reality in Koplak looks different compared to the reality which Balinese, especially those who live in a village on how treating and raising women. This issue relates to the issue of feminism and raising a daughter to be a feminist.

Feminism becomes a major issue that is discussed in Gender Studies. Feminism can be considered as a movement to remove the perspective of women objection which usually relates to the marginality of women (Caddell, 2015). Feminism usually fights for equality in economy, politics, and social life (Russell \& Cahn, 2013). Concerning the phenomenon in the novel, there is a relational phenomenon between feminism and the story of Koplak raising a daughter. He raises a daughter without comparing it to any male characters. He also thinks that having a daughter is the same as valuable as having a son. As a result, Koplak's daughter, Kemitir can choose to live by her own choice. Through this phenomenon, it can be seen that Koplak by Oka Rusmini brings up some problems that against Balinese culture, which are the free patriarchal Balinese daughter and a feminist father as it is seen through a feminist perspective.

This paper leads to the discussion of the issue of Feminism in the novel Koplak by Oka Rusmini. To explain the thesis statement, this study will use a descriptive qualitative method. It is the most suitable

Jurnal Lakon: Kajian Sastra dan Budaya 
method to do non-numerical data, such as a novel.

\section{LITERATURE REVIEW}

Feminism rises because of the phenomenon of the social hierarchy of male over female. Women are the object of inequality treatment in society and feminism is the movement against it. In the eye of feminist, the hierarchy of male and female exists. Feminism can be considered as a social and political movement or body of theoretical work (Barker, 2004). Feminist movement prepared to end the social domination of women and support gender equality in various aspects (Swirsky \& Angelone, 2015). Historically, feminism has various explanations regarding the definition of the term itself. The first wave feminism relates this term with the movement of gaining equal rights of suffrage for women. The second wave feminism defines this term as the movement to gain equality in working space, family, and sexuality (Freedman, 2001; Baxter, 2003). Through all of the explanation, it leads to a conclusion that feminism is a movement and a theoretical framework which is used to help women gaining equality in various aspects of society and politics. It helps women to live their life in a better situation (Tate, 2001).

Feminism develops and not only focuses on women's rights. As Swirsky and Angelone write that the ideology of feminist is "the need to recognize and disseminate the historical exploitation, devaluing, and oppression of women, the goal of improving women's social standing while working toward equality for all genders and groups, and the active criticism of traditional intellectual pursuits and gender ideologies (Swirsky \& Angelone, 2015)." Through this ideology, it can be seen that feminism not only take care of women and its inequality but also other's gender problem which happen to be same as women's. This ideology which is held by feminists centered on women's problems as seen through patriarchal culture. The ideology of feminist also offers the aims of this movement that is making women and all gender and groups socially equal. This ideology also actively gives critics over traditional intellectual pursuits and gender ideologies. These points are aiming to balance between women and men or any groups on every occasion.

\section{DISCUSSION}

This part of the study will be focusing on the work of Oka Rusmini's Koplak as the primary data which showing the phenomenon of supporting women's equality. This phenomenon is similar to the concept of feminism, which also fighting for women's equality, not only women but all gender and other groups. The phenomenon of free patriarchal women is seen through Kemitir.

Kemitir is portrayed as a woman who is not burdened by patriarchal value in Bali which usually happens to surround Balinese women. She shows how Balinese women does not always relate to a patriarchal culture. Kemitir shows it in three ways. First, she shows through speaking up her voice, even to her father. It shows in the quotation below.

"Kenapa Bape?"

"Untuk apa pemampilan kalau kerja tidak beres?"

"Untuk menunjukkan bahwa Bape sayang kepada diri Bape." 
"Bape sayang kepada diri Bape. Juga kepadamu"

"Kalau Bape sayang kepadaku, mulai saat ini Bape harus mengurangi makan daging. Bape bisa terserang hipertensi." "Bape tidak punya penyakit itu. Itu penyakit orang kaya."

"hipertensi itu bisa menyerang siapapun, tidak peduli kaya-miskin. Tuamuda. ... (Rusmini, 2019, pp. 34-35)"

Translation:

"why, dad?"

"What is the purpose of the appearance if it cannot work properly?"

"To show that you love yourself, dad." "I love myself. And you too."

"If you love me father, starting from now, you have to reduce eating meat. You can get hypertension."

"I don't have the disease. That belongs to rich people."

"Hypertension can attack anyone without concerning anything, rich-poor. Old-young. ... (Rusmini, 2019, pp. 3435)."

The quotation above shows the conversation between Koplak and his daughter Kemitir. Both of them are arguing about random things. Kemitir always says what she thinks is right, even though she has to argue with her father, like the simple conversation above.

Not only in Bali culture, usually men and women also pose a different frequency of talking and speak up what they think. This phenomenon usually is called silent women. A silent woman is a condition that makes women cannot speak up their ideas because of the environmental pressure and patriarchal culture (Fetzer, 1991; 吳若寧, 2011). The meaning of silent woman is suitable to express the condition of women in a patriarchal culture, which the women cannot comfortably and freely express anything in any conversation.

It is very different from Kemitir's case, she can say whatever she wants to say even to her father. If the woman who is silence represents a girl whose still in patriarchal value, a person like Kemitir will be on the opposite side. In other words, Kemitir is considered as a woman who is free from patriarchal values.

Another description of Kemitir's is free from patriarchal values is showed through her freedom to choose to live in a big city alone. The quotation is taken from koplak's thoughts about his life.

"Sejak anak perempuan semata wayangnya memilih hidup dan mengembangkan diri di kota, Koplak merasa Lindung adalah bagian dari masa depannya (Rusmini, 2019, p. 125)."

Translation:

"Ever since his only daughter chooses to live and develop herself in the city, Koplak feels Lindung is part of his future (Rusmini, 2019, p. 125).

A sentence above shows that Kemitir, as the only child for Koplak, chooses to live and develop herself in the city. The word "choose" on the sentence shows that Kemitir is someone who makes the decisions without being interrupted by Koplak. It means she is the woman who can choose anything she wants, for this case she chooses to be in the city (Denpasar).

As it is seen, Kemitir is someone who is not burdened by patriarchal values anymore. Her action is against the women

Jurnal Lakon: Kajian Sastra dan Budaya

e-ISSN: 2527-4899; p-ISSN 2252-8954 
who still believe in patriarchal values. Fakih says that in the scope of family women tend to be marginalized or limited to decision making (Fakih, 2005). Due to her difference compared to Fakih's statement, it leads to the conclusion that Kemitir is unmarginalized by her father, like the other marginalized women. This is what makes her become someone who is not following patriarchy values.

Last, but not least, the point which makes Kemitir is non-patriarchal Balinese is her job is not in domestic space, as usually women's do. It is seen through the sentences below.

... Selama ini dia terlalu disibukkan dengan bisnis kafenya di Denpasar. Bisnis yang makin berkembang melampaui impiannya. Gerai-gerai kopinya dibuka di tempat-tempat pariwisawa dan banyak "klien" dari pelbagai daerah luar juga luar negeri berusaha menawarkan beragam ide dan kerja sama yang menggiurkan.

Pada usianya yang ke-21, Kemitir telah sukses sebagai "pedagang kopi". Dahulu ketika kanak-kanak Kemitir ingat istilah "Dakocan", akronim dari "Dagang Kopi Cantik" (Rusmini, 2019, p. 106).

Translation:

... All this time, she is busy with her café in Denpasar. Her business is developed more than what she dreamt. Her coffee shops are opened in many tourist places and have many "clients" coming from various places outside Denpasar even overseas clients offers a lot of ideas and collaboration.

At the age of 21, Kemitir becomes a successful coffee businesswoman. A long time ago, when she was a child, she remembers a term "Dakocan", the acronym of "Dagang Kopi Cantik" (Selling Beautiful Coffee) (Rusmini, 2019, p. 106).

The paragraphs above show how successful Kemitir's business in a big city. It is explained through the words "developed" dan "have many clients". Both phrases show that a woman can run a business and become a successful woman. Even though she is still young, she shows her ability to be a businesswoman. Remembering the term Dakocan shows that her achievement in selling coffee is great. All things which she does is showing that women do not relate to domestic works and can spread her wings.

Women and domestic works, such as cooking and cleaning house are like two pieces of words which cannot be separated. Ibrahim argues, "They (wives) have to confined within four walls of their own house, and at the same time their husband freely reached as much as they can in the public sphere (Ibrahim, 2013)." It shows that women are supposed to be inside the house while men are freely working in a public place. It is a very patriarchal mindset, while Kemitir's case is against it. It makes her consider a person who is not in a patriarchal scope.

Everything which has been shown through the explanation above makes a strong conclusion that Kemitir is a woman who is different from the perspective of Balinese culture. She is not limited by cultural value which usually surrounds Balinese women. It shows that Balinese culture actually can be negotiated.

Jurnal Lakon: Kajian Sastra dan Budaya 
After the appearance of Balinese women which is not following the traditional value, there is a question regarding who is someone behind it? The answer is quite simple. It is because of her surrounding like family which makes her life differently. In the case of Kemitir, she has a feminist father. Even though feminist is usually related to woman, but in Koplak by Oka Rusmini, there is a character who poses a feminist character and he is male. This character is Koplak himself. He shows his feminist side in three ways.

First, he teaches her daughter to speak up her mind. In order to make her daughter freely from the patriarchal burden, Koplak designs his way to educate Kemitir. It is depicted through the quotation below.

Bertengkar dengan Kemitir juga percuma. Sejak kecil Kemitir memang dididik Koplak untuk mandiri. Untuk berani mengatakan apa pun tanpa melihat bahwa dirinya seorang perempuan (Rusmini, 2019, p. 35).

Translation:

Arguing with Kemitir is useless. Since her childhood, she is taught to be independent. To be brave to speak up without seeing herself as a woman (Rusmini, 2019, p. 35).

The quotation above is actually what is inside Koplak's mind. He thinks about the reasons arguing with her daughter is useless. It makes sense because Koplak raises her as someone brave to speak what she thinks without considering her sexuality or gender. As a result, in every conversation with Koplak Kemitir always states what she thinks is right. Even she needs to talk back to her father.

By teaching a child to freely speak means teaching children to understand that everyone has a chance to speak, even she is a woman. It means that as a father, he knows that patriarchal values should not be applied in his children, even if the consequences will be "answering back to parent's statement." This action is seen as a movement of feminists. In chapter two, there is a statement that feminism is trying to make women equal to men on any occasion. If the father does this, means he also part of the movement and also a feminist.

Second, to be a feminist everyone should treat women and men equally. Koplak is also doing this. It makes him concluded as a feminist. This statement is based on the quotation below.

Selama ini Koplak selalu berpikir semua anak yang dilahirkan itu sama. Tidak ada yang lebih unggul. Tidak ada yang lebih menguntungkan. Tidak juga lebih dari segalanya. Anak perempuan dan lelaki itu sama saja. Memangnya kalau Tuhan memberi anak perempuan, lalu kita menginginkan anak lelaki, anak perempuan yang sudah dilahikan itu bisa ditukar? Dijual? Digadaikan? Atau dibuang (Rusmini, 2019, p. 158)?

...

Selama ini koplak merasa hidupnya baik-baik saja. Apa yang mesti ditakutkan? Koplak juga berkorban banyak untuk kemajuan Kemitir. Bahkan, saat ini bagi koplak Kemitir itu seperti lelaki sekaligs perempuan. Beragam hal bisa diselesaikan dengan cepat. ... (Rusmini, 2019, p. 159) 
Translation:

All this time Koplak always thinks all children are born the same. There is no superiority in them. There is no more profitable. There is no more than anything. The daughter and son are the same. If God gives daughter, while we want a son, can our born daughter be exchanged? Sold? Mortgaged? Or thrown away? (Rusmini, 2019, p. 158)

All this time Koplak has been fine with his life. What does make him afraid? Koplak also fights for Kemitir's development. Even, this time Koplak thinks that Kemitir is a man and a woman. Everything is done fast. ... (Rusmini, 2019, p. 159)

The key to the quotation above is thinking equally. Koplak as a father never thinks that his daughter is lesser than male. He believes that every child is a gift from God with no superiority between them. Koplak makes some questions regarding having a daughter. It leads to an insinuation. Koplak has a mindset that a girl can develop and a woman also can work as fast as male.

Treating and seeing someone without seeing his/her gender or sexuality is considered as a person who is part of removing inequality in society. In the definition of feminism, it is seen that feminism is a movement that fights for equality, especially for women. By treating and consider women and men are the same human being, it means he is trying to make the inequality in women lesser. In this case, Koplak shows that a father can also be the agent to share this. It makes sense that a father also can be a feminist.

Last, but not least, as a father Koplak let her children choose her future. It is seen in the quotation below.

Terbayang anak perempuannya. Sejak menyelesaikan kuliah di Denpasar, anak perempuannya itu begitu mandiri. Bagi koplak, anak semata wayangnya itu mengelola pekerjaannya dengan baik (Rusmini, 2019, p. 77).

Translation:

Imagined his daughter. Since her graduation in Denpasar, her daughter becomes independent. For Koplak, his only child can manage her job well (Rusmini, 2019, p. 77).

The quotation above is emphasized on the word "become independent" and "manage her job well". These two words give meaning that Koplak's children decide to live independently and working as a businesswoman selling coffee. The description which Koplak makes shows no interruption or protest on his daughter's choice. Even she has to live far away, the sense of the quotation above showing no regret. By this, it shows that Koplak never thinks about deciding for his daughter.

Letting a daughter have their own choice is equal to make a girl free from marginalization. The issue of feminism usually related to marginalization which one of the implementations is limiting a woman in making choices (Fakih, 2005). Marginalization can lead to someone live inequality because she cannot live her life. On the contrary, someone who is trying to let a woman choose her future can make marginalization's phenomenon lesser. It

Jurnal Lakon: Kajian Sastra dan Budaya

e-ISSN: 2527-4899; p-ISSN 2252-8954 
leads to someone who has a similar action as a feminist. If a father doing this, he can be considered as a feminist.

Through all of the explanations, it can be seen that Koplak is the representation of a father and the reason for Kemitir's life path. She has a lot of rights to choose her life and become someone free from patriarchal culture. Kemitir is showing how a Balinese girl can be free from patriarchy, even though her surroundings still hold this culture. The appearance of the feminist father leads into a daughter live equal, by letting the daughter choose her life and think that they are the same human comparing to the male is the right way.

\section{CONCLUSION}

The patriarchal culture surrounding Balinese women is a common phenomenon in real life. It is easy to see a woman still living under the burden of this culture. As a result, a lot of woman with Balinese culture is hard to express and explore herself, especially in the public sphere. But, in the lates work of Oka Rusmini's Koplak, she tries to show that Balinese women are not always related to patriarchy. Without any statement of being feminist, someone can be free from this burden. Kemitir is the character who is representing Balinese women is free from patriarchal values. She appears with the freedom to speak and live her life. She also does not relate to any domestic works as Balinese women always stereotyped. By seeing the appearance of Balinese women, it can be concluded that patriarchal culture in Bali can be negotiated or even no longer applied to any women in Bali. Even though the person never states of being a feminist, she can be free women to live her life.
The main reason for this negotiation is the appearance of the feminist father. Becoming a feminist is not always for women. A male can be a feminist as long as he acts like a feminist to make a change related to gender inequality. In Oka's work, a feminist father is shown through Koplak. He makes himself a feminist for her daughter. He treats her daughter equally to men and let her daughter choose her future life. These actions are considered feminist actions because what he does is making women exist in the public and private places. After all, the appearance of a feminist father is important for a daughter. It helps the daughter free from patriarchal culture. Nowadays, a feminist father exists. On the other words, one of the solutions to remove inequality in any cultural value can be started by parents. Being a feminist parent can lead to raising children with feminist values.

\section{REFERENCES}

Barker, C. (2004). The SAGE Dictionary of Cultural Studies. London: SAGE Publication.

Baxter, J. (2003). Positioning Gender in Discourse A Feminist Methodology. Hampshire: Palgrave Macmillan.

Caddell, A. A. (2015). From center to margin: Feminism in an era of mainstream co-optation.

Dissertations, University of Alabama.

Fakih, M. (2005). Analisis Gender dan Transformasi Sosial. Yogyakarta: Pustaka Belajar.

Fetzer, G. W. (1991). Women's Search for Voice and Tthe Problem of Knowing in The Novels of Mariama BÂ. CLA Journal, 31-41.

Freedman, J. (2001). Concepts in the Social Sciences Feminism. Buckingham: Open University Press. 
Ibrahim, S. (2013). Hukum Domestikasi dan Kepemimpinan Perempuan dalam keluarga. Jurnal Al-Ulum, 215-244.

Rusmini, O. (2019). Koplak. Jakarta: Grasindo.

Russell, H. L., \& Cahn, S. K. (2013). A "telling" uproar: Young women, feminism, and the making of the third wave. Dissertation, State University of New York.

Sudarta, W. (2017). Pengambilan Keputusan Gender Rumah Tangga Petani pada Budidaya Tanaman Padi Sawah Sistem Subah di Perkotaan. Jurnal Manajemen Agribisnis, 59-65.

Swirsky, J. M., \& Angelone, D. (2015). Equality, Empowerment, and Choice: What Does Feminism Mean to Contemporary Women. Journal of Gender Studies.

Tate, H. (2001). Toward a Rhetorical History of Feminist Identity: The Negotiation of Feminist Identity in Contemporary American Discourse. Dissertation, Indiana University, Department of Communication and Culture.

Widayani, N. M., \& Hartati, S. (2014). Kesetaraan dan Keadilan Gender dalam Pandangan Perempuan Bali: Studi Fenomenologis terhadap Penulis Perempuan Bali. Jurnal Psikologi Undip, 149-162.

吳若寧, N. C. (2011). Re-Orientalizing Chinese Silence with Chinese American Orientation in Maxine Hong Kingston's "The Woman Warrior" / 從美籍華裔的身份角度出 發：探討湯 亭亭 《女勇士》内中 國沉默形象的轉化. Journal of Oriental Studies, 63-76. 